\title{
Economic Analysis of American Yam Bean and Implications for Food Security in Nigeria
}

\author{
Udemezue $\mathrm{JC}^{1 *}$ and Onwuneme $\mathrm{NA}^{2}$ \\ National Root Crops Research Institute, Nigeria
}

Submission: September 15, 2017; Published: October 02, 2017

*Corresponding author: Udemezue JC, National Root Crops Research Institute, Umudike, PMB7006 Umudike Abia State, Nigeria, Tel: +2348038971076; Email: udemezuej@gmail.com

\begin{abstract}
The roles of American yam bean for the benefit of mankind should not be underestimated, American yam bean is a great source of different vitamins and minerals. It is one of the neglected root crops that can boost the capacity of food security of a nation if its potential is properly harnessed. In view of these, this paper employed analytical approach to review; economic importance of American yam bean, technology package for American yam bean, American yam bean flour flow chart and a report on field trial of American yam bean.
\end{abstract}

Keywords: American yam bean, potentials, food security

\section{Introduction}

American yam bean (AYB) is one of the neglected edible tuberous root crops that belong to the genus of "pachyrhizus". It originated from central and south America in the head-water region of the river Amazon and was cultivated there in pre-Columbia days. The Spaniard spread it to the Philippines and it is now cultivated and naturalized in the Philippines, Gambia, China, Indonesia, Northern India, Western and Northern South America, and the Caribbean $[1,2]$.

According to Amadi, Egesi, [3] American yam bean was first introduced in some African countries but not in Nigeria, later fourteen accessions of AYB were received in Nigeria from International Potato Centre (CIP), Lima in March, 2013. The accessions were received in the form of true seeds as to evaluate the performance of this crop in Nigeria.

It is a leguminous plant which related to soya bean but not, its tubers can be eaten raw or processed into a number of products including garri (Padonou, Nounyevou, Ahounou, Fandoha, Aihou, Adjanohoun, Hell, Adegbola, Mensah and Koudande [4]. American yam bean seeds contain toxic (rotenone) and are not edible, the roots are edible and are significantly richer in protein, iron and zinc than that of cassava, sweet potato and yam (Partnership for yam bean, 2013).The root of American yam bean is yellow and papery while the inside is creamy white with a crisp texture that resembles raw potato or pear. The flavour is sweet and starchy, reminiscent of some apples or raw green beans and can be eaten with salt, lemon or lime juice and chili powder.

Despite the roles of American yam bean as an important crop for food security, the crop has not been able to receive enormous attentions in some countries like Nigeria due to lack of information as regards to its production to boost food security. As a result of this, it behooves the paper to review the various roles, technology packages and economic importance of American yam bean in respect to food security.

\section{Economic Importance of American Yam Bean}

The roles of American yam bean for the benefit of mankind should not be overlooked, with the available literate, American yam bean is a great source of different vitamins and minerals. It contains an excellent source of vitamin C, fibre, potassium, iron, calcium and low sodium (Kanikakhara, 2013). Due to its low in calories and fat, AYB helps to control the cholesterol levels and reduces the risks of having heart problems such as heart attack, hypertension etc. American yam bean acts as a powerful antioxidant and anti-inflammatory due to its high levels of vitamin C. its anti-inflammatory properties benefit by subsiding the symptoms of asthma like wheezing especially in young children and being rich in vitamin $\mathrm{C}$, helps to control and cure common cold and flu. 
People who suffer easy bruising can overcome this problem by increasing their vitamin $\mathrm{C}$ intake there by including American yam bean (Jicama) in their daily diet. It straightens and supports the structure of capillaries thereby reducing the risks of having capillary fragility. It is rich in folic acid, beta-carotene and many other vitamins and because of these, American yam bean is effective in lowering the homocysteine levels in the body. Homocystein is an amino acid that affects the cellular metabolism and production of proteins in the body and can also increase the risks of heart disease by damaging the lining of blood vessels. All in all, American yam bean boosts the body's immune system and helps in enhancing the overall body functioning.

In view of the above, it is therefore interesting, educative and scintillating to carry out further research as to unveil more on the economic values of American yam bean therein and this would as well help to retardate the speed of food insecurity in Nigeria.

\section{Technology Package for American Yam Bean}

\section{Soil type}

Choose fertile land with a moderately water holding capacity. The best soil for American yam bean is sand loamy; it will also tolerate well drained clay soils but not heavy soils liable to become water logged. American yam bean is tolerant to various climates, but for optimum yield it requires fairly high temperatures and a moderate to high rainfall. It grows well in the hot, wet tropics. American yam bean is normally grown at altitudes below $100 \mathrm{~m}$ [1]. In terms of photo thermal neutrality, American yam beans are short-day plant, that is flowering and tuber production will only take place under decreasing day length. But field studies/ observation and experiments conducted under green house conditions have demonstrated the existence of genotypes with reduced or almost absent photo thermal sensitivity. Therefore Day-length-short days are necessary for tuberization. When grown under a 14-15 hour photo period the vegetative growth is good, but there is little production of tuberous roots, short day length gives smaller, bushier plants and good tuberization [2].

\section{Land preparation}

Land is cleared of the debris with hoes and machetes. It could be also slashed and harrowed mechanically using tractor but this depends on the farming system practicing by the farmer. Then, thrashes are collect and burnt. It could be planted on the flat land or on ridges depending on whether it is rain-fed or irrigated American yam bean production.

\section{Seed selection}

Since the variety has been selected, make sure that the seed is of good qualities. Poor seeds will not produce a good crop and may definitely result to input wastage. Seeds with a good quality have a uniform colour and can be tested by planting 2 percent of them as a germination test.

\section{Planting material}

In general, American yam beans are grown from sprouted roots saved from the previous crops. It has been recommended that this practiced be followed to maintain desirable characteristics in the plants. The seeds are normally sown at the beginning of the rains, either on the flat or in ridges, the later gives better results. Usually, 1-2 seeds are placed in each hole and the plants thinned out as necessary or the seed may be planted single by drill. In some cases, 2-3 seeds are usually planted per a hole. The recommended seed spacing for India is $15 \mathrm{~cm}$ along rows $50 \mathrm{~cm}$ apart, in the Philippines a spacing of $10 \mathrm{~cm}$ in rows $15-20 \mathrm{~cm}$ apart is common practice. In Nigeria, $1 \mathrm{~m}$ is highly effective for field spacing. However, it has been shown experimentally that the yield of roots doubled when a spacing of $15 \times 15 \mathrm{~cm}$ was used. Provision of bamboo trellised about $2.5 \mathrm{~m}$ high to support the vines had been found beneficial but is not essential. Therefore, American yam bean could be staked for optimum ventilation and better tuberlization. Sometimes, the plants are pruned as to encourage vegetative growth and the removal of the flower is reported to increase tuber yields and improve their flavour. Therefore reproductive pruning is essential to obtain maximum yields. Seed rate: $20-25 \mathrm{~kg} / \mathrm{ha}$ of seed is used for planting provided the germination rate is $90-95$ percent. In India, a higher seed rate, $50-70 \mathrm{~kg} / \mathrm{ha}$ is preferred [5].

\section{Weed management}

The crop is kept free from weeds and is often mulched to help conserve soil moisture and prevent weed growth. Experiment has shown that weed infestation reduces $60 \%$ performance of the American yam beans. Manual weeding is recommended few weeks after planting and should be regularly checked against weeds. Use of herbicides could also be used to control weeds.

\section{Fertilizer application}

In general, no fertilizer application is needed, although adding phosphorous may be recommended to obtain the optimal biological nitrogen fixation. Fertilization with an N,P,K, fertilizer (10-30-10) may be used in some communities. For high yields, the application of a 12:24:12 NPK fertilizer at the rate of 300$400 \mathrm{~kg} / \mathrm{ha}$ before planting has been recommended, followed by $200 \mathrm{~kg} / \mathrm{ha}$ of ammonium sulphate when the plant is about to climb. Moreso, if the soil has been heavily cropped, it is suggested that it should receive 10t/ha of compost or FYM, about a month before planting.

\section{Pest and Disease}

Diseases and pests of American yam bean are identified according to the observations made with some cultivated varieties available within the different locations. There is little doubt that regardless of the disease inflicting organism, the majority of both the diseases and insect pest will in fact be common to all species. In Central America, American yam bean is reported to be subjected to attack the larvae of Thecia Jebus and Ferrisa 
Virgates. In Mexico, the seeds are often attacked by weevils, in the Philippines, a mosaic disease has been noted which is caused by a systemic virus transmitted through the seed or root. A slight mottling or chlorosis and blistering of leaves, together with the production of very small tubers are characteristics symptoms. A bacterial leaf spot caused by pseudomonas syringae has also been reported. However, the differences recorded among various locations in terms of pest and diseases occurrences are due to geographic, climatic, ecological and endaphic conditions. Witch's broom disease was first diagnosed by Thung and Hadiwidjaja 1957 and is caused by mycoplasma like organisms, the most likely vectors of these disease are a number of species of leaf-piercing insect pest. They are aphid (Aphis rumicis L, Brevicoryne Brassicae L., Oregma lanigera Zenthner). Mealy bug (Ferrisa Virgata Cokereu) and white flies. The typical symptoms are irregular chlosis of the leaves, young shoots becoming brittle and the seed set being reduced as a result of atrophied pollen (the pollen fertility of the infected plant is reduced from 95$100 \%$ to less than $10 \%$. Tuber growth is also affected and yield will decrease by $20-40 \%$. Bean halo blight is a bacterial disease of AYB which caused by pseudomonas syringae. The disease has been observed in many field trails and does not appear to reduce yields significantly. Fungi have been reported by several researchers to be the cause of severe damages on American yam bean. High motility rate in young plants as a result of "root rot" is caused by fungi called pythium apphjanidermatum and another severe leaf spot disease observed in Bhubaneswar and India are also caused by fungi named cercospora canescens. Another high mortality rate in young plant as a result of "root attacks" is caused by fungi called pythium spp, corticium spp and macrophomina spp. In all, it has been observed from field trails that when about five species of American yam bean are cultivated in one location, bean common mosaic virus (BCMV) will infect about three cultivated species while the wild species (P. panamensisi) be infects with some delay due to the prominent hairiness of all vegetative parts which has a repelling effect on the aphid vectors.

Nematodes attacks tuber and therefore reduce tuber quality of American yam bean. The symptoms are described as "warts" which give the effected tubers a bitter taste. With the available literature, several nematodes have been reported as being the cause of significant yield reduction in the crop. This observation was confirmed by the first trial conducted during raining season in Igbariam location Anambra state, Nigeria. A number of insect pests are reported to cause lead, tuber and seed damage in American yam bean. However, species belonging to the genus Diabrotica are serious pests in many humid area and the leaf damage is often quite extensive, although differences in susceptibility between accessions have been recorded that is more hairy genotypes tend to suffer less from the attacks. In tonga, rose beetle (Adoretus versutus Harold) has been identified as the main cause of leaf damage. In Mexico and Central America, flower buds and the young pod could be damaged by Thecla
Jebus. Plants in a recent field trial (2015) at Igbariam community, Anambra state were seriously not attacked by pests and also not considered serious problems in some varieties selected. In the location, termites (Termitidae) were identified as a major problems and destroyer of the plant. Termites hollowed the stems of young plants and destroying about $10-15 \%$ of the plant. These are another unidentified larva that attack the plant and caused severe leaf damages in Igbariam location.

Seed damage caused by the coffee bean weevil has been recorded in seed belonging to all varieties during storage. Even though the mature seed have the highest amount of endogenous rotenone of any part of the plant, it is the seed that suffers the most serious attack by an insect pest such as the bean weevil (Bruchideae). In Nigeria, the most severe tuber damage observed was not rot and this may be due to lack of irrigation management system in the locality. No other serious damage caused by pest or diseases during the vegetative time was recorded and this may be attributed to the presence of rotenone in the leaves and stems of the plants.

Locally, in very humid conditions such as those in province of Esmeraldas, Ecuador, among others, leaf eating insects such as the species belonging to the genus Diabrotica and Disonycha glabrata F may cause extensive damages on the crops. Several nematodes have been reported as being the cause of significant yield reductions in the plants. In Brazil Noda et al. 1991 in Karly \& Joachin [6]. observed serious damage caused by the attack of Meloidogyne Goeldi and pratylenchus filiojev. This observation was confirmed by the first field trail conducted during the rainy season in Esmeralda, Ecuador where one accession belonging to the Jiquima cultiva group (P. tuberous) did not produce any marketable tubers due to nematode (meloidogyne) damage. With regards to the observations made from field trial 2015 in Igbariam community, the insect damage observed elsewhere in the literature review also seemed to be a problem in Igbariam field trial where "the white fly complex" (A leutotriachelus sp., Bemisia sp. Alerothrixus sp. Homoptera, Fam, Alegrodiadae) had been observed in the varieties.

\section{Effective control}

Use of crop rotation and non-infested fields are used as control measures. Use of hand picking method could be recommendable to a small scale of land. Use of chemical to suppress leave-eating insects and isolation of the infested plant should be destroyed objectively. Use of crop resistant varieties. Some varieties are more resistant to other varieties, therefore find out and use them.

\section{Harvesting}

American yam bean normally reaches maturity between 5-8 months, although in the warmer parts of Mexico the commercial is obtained in about 3 months. The time of maturity could be 10 months approximately if a seed crop is required (Kanika Khara 2013). However, recent trail conducted on American yam bean 
in Nigeria indicated that the crop could attain maturity between 5-7 months even if a seed crop is required. Falling of dry leaves and dehydration of the stems are the symptom of the maturity.

\section{Handling}

The root is usually dug manually with hoe and removed gently to avoid scratching that can reduce its market value. Though, with large-scale production they can be sometimes ploughed out. The tops are trimmed entirely, washed roots and packed in baskets or ventilated bags for market. The cream colour of the skin changes within 24 hours to a purplish brown, but this can be stopped once the roots are stored in the dark temperature at 9-10 ${ }^{\circ} \mathrm{C}$. However, they can be stored comfortably for at least 2 months at a temperature just above $00 \mathrm{C}$. Older roots tend to store better than tender immature ones. With reference to literature, there can be "field stored", in Mexico, the normal practice is to withhold irrigation water thereby stopping growth and the roots will remain in good condition in the soil for 2-3 months. Once the farmer wants to harvest, it will be irrigated to absorb water and can be marketed in the usual way. In summary, harvest takes place once the tuberous roots have attained marketable sizes depending on whether small, medium sized or large tubers are preferred by the consumers. Proper care should be taken when uprooting American yam bean with hoe to avoid damages that may reduce its market value.

\section{Postharvest handlings}

American yam bean is only species in which post-harvest and storage handling has been studied in some details. However, the chilling sensitivity of the tuberous roots has been demonstrated [6]. Low temperature storage has been found to reduce storage life considerably and the optimal storage temperatures are between 12.5 and $17.5{ }^{\circ} \mathrm{C}$ respectively. Washing, trimming (removal of the non-tuberous part of the root and the basal part of the stem) and dipping in a high concentration chlorine solution to obtain sterilizing and bleaching effects were the only post-harvest treatment reported. Prolonged storage will serve to alter the starch/sugar ratio. Paul \& Jungchen and in Karl \& Joachin [6] found in their studies that after 3 months of storage at $12.50 \mathrm{C}$, the sucrose content tripled and only one-sixth of the starch remained and this could be the reasons why some consumers leave the tubers in a sunny place for up to 2 weeks prior to marketing as to produce sweeter tubers. Moreover, if the entire plot containing the crop is to be harvested in one operation, the tubers of the American yam bean may be stored for 22-30 days during the post-harvest stage, provided that wellventilated indoor conditions are maintained. American yam bean could be processed into composite flours that could be used as confectionaries. Using the approach described by Aniedu and Oti [5] in Nwadili et al. [1] American yam bean could be processed as follows (Figure 1).

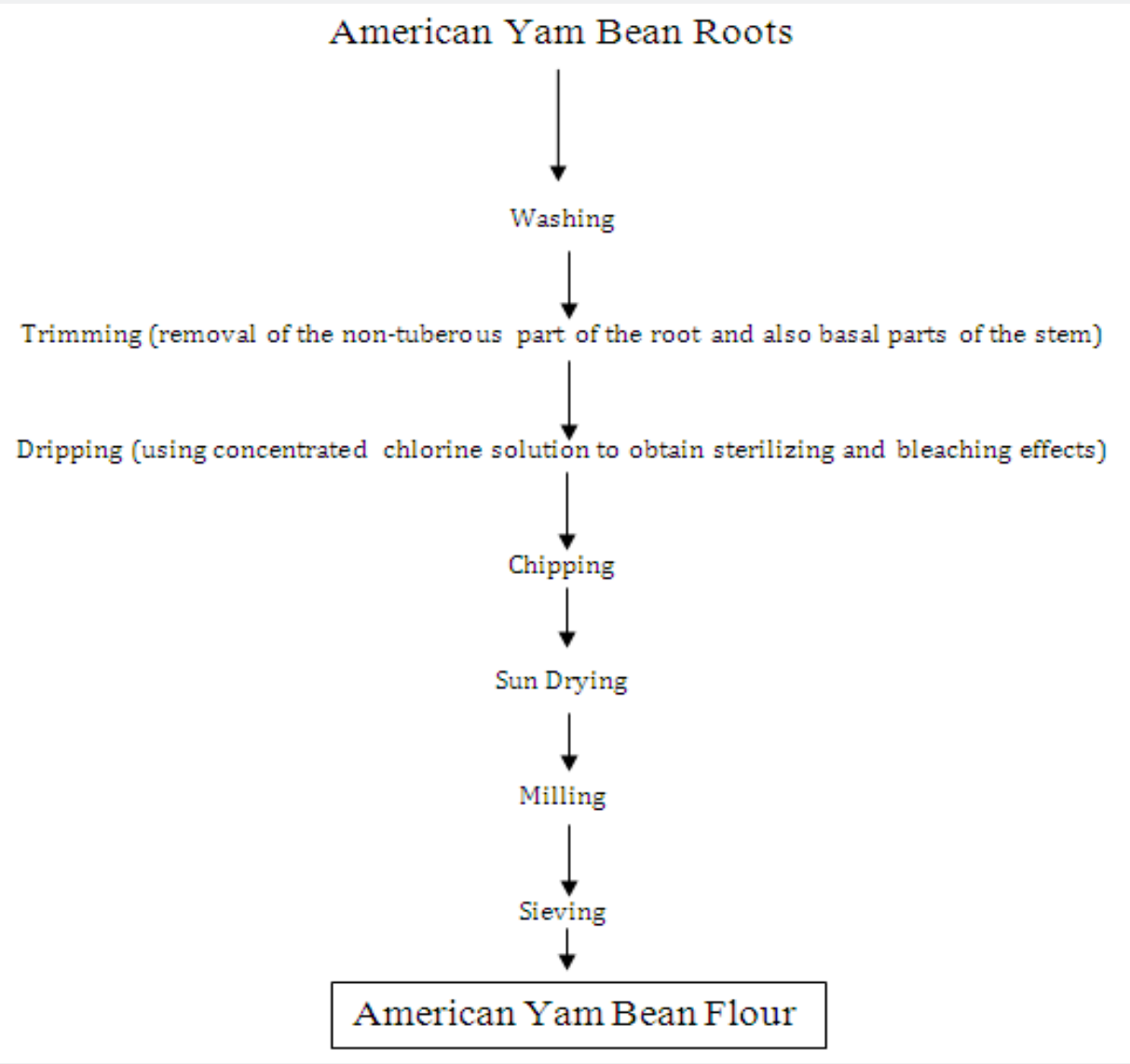

Figure1: American Yam Bean Flour Flow Chart. 


\section{A report on american yam bean experiment, 2015 at igbariam sub-station}

Location: National Root Crops Research Institute Igbariam Sub-station, Anambra State, Nigeria.

Objective: To determine the performance of American Yam Bean in Igbariam soil.

Total Hectare: 0.0036ha

Varieties Planted/seed number: 209015, 209016, 209018, 209039, 209045, 209013 and 209019 (Table 1).

Table 1

\begin{tabular}{|c|c|}
\hline Varieties & Seed Number \\
\hline 209015 & 40 \\
\hline 209016 & 40 \\
\hline 209018 & 40 \\
\hline 209039 & 40 \\
\hline 209045 & 40 \\
\hline 209013 & 20 \\
\hline 209019 & 10 \\
\hline
\end{tabular}

Source: field survey, 2015.

Land Preparation: The land was ploughed, harrowed and ridged by tractor.

Date Planted: 20 ${ }^{\text {th }}$ May, 2015.

Planting Distance: $25 \mathrm{~cm}$ by $1 \mathrm{~m}$

Time of Emergence: 8 days after planting (Table 2)

Table 2

\begin{tabular}{|c|c|}
\hline & \% Plant Emergence: \\
\hline $209015=27 / 40 \times 100 / 1$ & $67.50 \%$ \\
\hline $209016=24 / 40 \times 100 / 1$ & $60.00 \%$ \\
\hline $209018=30 / 40 \times 100 / 1$ & $75 \%$ \\
\hline $209039=26 / 40 \times 100 / 1$ & $65 \%$ \\
\hline $209045=21 / 40 \times 100 / 1$ & $25.50 \%$ \\
\hline $209013=13 / 20 \times 100 / 1$ & $65 \%$ \\
\hline $209019=7 / 10 \times 100 / 1$ & $70 \%$ \\
\hline
\end{tabular}

Time of Climbing: $2^{\text {nd }}$ July, 2015.

Plant Height (cm): (Table 3)

Table 3

\begin{tabular}{|c|c|c|}
\hline Var. 209015 & Var. 209018 & Var. 209045 \\
\hline $112.1 \mathrm{~cm}$ & $250.3 \mathrm{~cm}$ & $140.1 \mathrm{~cm}$ \\
\hline $250.6 \mathrm{~cm}$ & $158.2 \mathrm{~cm}$ & $96.35 \mathrm{~cm}$ \\
\hline $50.0 \mathrm{~cm}$ & $240.1 \mathrm{~cm}$ & $36.1 \mathrm{~cm}$ \\
\hline $205.1 \mathrm{~cm}$ & $335.5 \mathrm{~cm}$ & $70.0 \mathrm{~cm}$ \\
\hline $102.5 \mathrm{~cm}$ & $217.5 \mathrm{~cm}$ & $180.6 \mathrm{~cm}$ \\
\hline $35.9 \mathrm{~cm}$ & $143.7 \mathrm{~cm}$ & $75.3 \mathrm{~cm}$ \\
\hline Var. 209016 & Var. 209039 & Var. 209013 \\
\hline $203.5 \mathrm{~cm}$ & $196.3 \mathrm{~cm}$ & $202.0 \mathrm{~cm}$ \\
\hline $50.0 \mathrm{~cm}$ & $217.2 \mathrm{~cm}$ & $313.2 \mathrm{~cm}$ \\
\hline $121.3 \mathrm{~cm}$ & $210.2 \mathrm{~cm}$ & Var. 209019 \\
\hline $305.2 \mathrm{~cm}$ & $155.2 \mathrm{~cm}$ & $293.2 \mathrm{~cm}$ \\
\hline $175.2 \mathrm{~cm}$ & $207.4 \mathrm{~cm}$ & $246.3 \mathrm{~cm}$ \\
\hline
\end{tabular}


Note: Var. stands for varieties.

Fertilizer Application: $7^{\text {th }}$ July, 2015

Time of Flowering: $20^{\text {th }}$ July, 2015 (Table 4)

Table 4

\begin{tabular}{|c|c|}
\hline \multicolumn{1}{|c|}{ Plant Performance } & Performance \\
\hline Varieties & 5 \\
\hline 209015 & 5 \\
\hline 209016 & 5 \\
\hline 209018 & 5 \\
\hline 209039 & 5 \\
\hline 209045 & 0 \\
\hline 209013 & 0 \\
\hline 209019 & \\
\hline & \\
\hline
\end{tabular}

Note: $0=$ very poor, $5=$ highly vigorous

Time of Maturity: $30^{\text {th }}$ November, 2015

Date Harvested: $14^{\text {th }}$ December, 2015

\section{Disease damages and number of tubers per stand (Table 5)}

Table 5

\begin{tabular}{|c|c|c|}
\hline Varieties & Number of Tubers Per Stand & Damages \\
\hline 209015 & 1 in all & 5 \\
\hline 209016 & $3^{2}$ and 1 & 1 \\
\hline 209018 & $1^{3}, 2^{6}, 6^{2}$ and 1 & 6 \\
\hline 209039 & $1^{2}$ and 1 & - \\
\hline 209045 & $1^{3}, 2^{2}$ and 1 & - \\
\hline 209013 & $3^{2}$ and $2^{3}$ & - \\
\hline 209019 & 1 in all & \\
\hline
\end{tabular}

Note: $3^{2}$ means that three plants among the whole stands in one variety produced two tubers per a stand and this therefore, applies to other superscripts therein (Table 6-10).

Table 6

\begin{tabular}{|c|c|}
\hline \multicolumn{2}{|c|}{ Tuber Fresh Weight } \\
\hline Varieties & Weight \\
\hline 209015 & $1.420 \mathrm{~kg}$ \\
\hline 209016 & $2.920 \mathrm{~kg}$ \\
\hline 209018 & $5.000 \mathrm{~kg}$ \\
\hline 209039 & $1.400 \mathrm{~kg}$ \\
\hline 209045 & $3.800 \mathrm{~kg}$ \\
\hline 209013 & $1.800 \mathrm{~kg}$ \\
\hline 209019 & $1.200 \mathrm{~kg}$ \\
\hline
\end{tabular}

\section{Table 7}

\begin{tabular}{|c|c|}
\hline \multicolumn{2}{|c|}{ Tuber Dry Weight } \\
\hline Varieties & Weight \\
\hline 209015 & $0.380 \mathrm{~kg}$ \\
\hline 209016 & $1.60 \mathrm{~kg}$ \\
\hline 209018 & $1.201 \mathrm{~kg}$ \\
\hline
\end{tabular}




\section{Modern Applications of Bioequivalence \& Bioavailability}

\begin{tabular}{|c|c|}
\hline 209039 & $0.800 \mathrm{~kg}$ \\
\hline 209045 & $2.60 \mathrm{~kg}$ \\
\hline 209013 & $0.90 \mathrm{~kg}$ \\
\hline 209019 & $0.300 \mathrm{~kg}$ \\
\hline \multicolumn{2}{|c|}{ Seed Weight: } \\
\hline Varieties & Weight \\
\hline 209015 & $0.520 \mathrm{~kg}$ \\
\hline 209016 & $0.260 \mathrm{~kg}$ \\
\hline 209018 & $0.1 \mathrm{~kg}$ \\
\hline 209039 & $0.160 \mathrm{~kg}$ \\
\hline 209045 & $0.080 \mathrm{~kg}$ \\
\hline 209013 & $0.040 \mathrm{~kg}$ \\
\hline 209019 & $0.050 \mathrm{~kg}$ \\
\hline
\end{tabular}

\section{Table 8}

\begin{tabular}{|c|c|c|}
\hline & Damages of Stem and Leaves by Insects and Fungi & Fungi \\
\hline Varieties & Insect & 0 \\
\hline 209015 & 0 & 0 \\
\hline 209016 & 0 & 6 \\
\hline 209018 & 0 & 6 \\
\hline 209039 & 0 & 0 \\
\hline 209045 & 6 & 0 \\
\hline 209013 & 0 & 0 \\
\hline
\end{tabular}

\section{Table 9}

\begin{tabular}{|c|c|}
\hline & Number of Pod Per Plant \\
\hline Varieties & Pod Number per Plant \\
\hline 209015 & $30,40,15,60,15,10$ \\
\hline 209016 & $10,15,11,20,13,21$ \\
\hline 209018 & $15,40,15,10,8,11$ \\
\hline 209039 & $11,10,20,30,21,9$ \\
\hline 209045 & $7,3,10,8,11,8$ \\
\hline 209013 & 3,5 \\
\hline 209019 & 10,3 \\
\hline
\end{tabular}

\section{Table 10}

\begin{tabular}{|c|c|}
\hline & Seed Number per Pod: \\
\hline Varieties & Seed Number per Pod \\
\hline 209015 & $3,6,7,8,6,7$ \\
\hline 209016 & $7,8,3,4,9,5$ \\
\hline 209018 & $8,9,10,6,3,7$ \\
\hline 209039 & $9,7,6,8,4,5$ \\
\hline 209045 & $3,7,8,6,7,4$ \\
\hline 209013 & 7,8 \\
\hline 209019 & 8,9 \\
\hline
\end{tabular}

Note: 0 means no damage, 6 means highly damage. 


\section{Observation}

It is observed from the trial that American yam bean could adapt soil condition of Igbariam community if properly maintained and this could as well boost food security of the nation once its potential is completely harnessed.

\section{Conclusion and Recommendations}

The ability of American yam bean to salvage a nation from the incessant food insecurity is still unknown to some farmers because it is one of the neglected root crops whose potentials are latent and untapped. Based on this, it behooves this paper to review the economic importance of American yam bean and the technology package for the crop in order to rekindle the spirit of farmers on the values of the underutilized crop. This paper, therefore, recommends that extension services should be made more effective to disseminate information on American yam bean to farmers, government at all levels should encourage extension agents to educate farmers the potentials and agronomic practices of the crop ,more hectares of land should be allocated to the crop rather than small portion of land as to harnessed its potentials in totality and there should be a workshop or seminar on American yam bean production in order to popularize the crop to farmers.

\section{References}

1. Nwadili VU, Omodamiro RM, Amadi CO, Aniedu C, Egesi CN, et al. (2014) Evaluation of American yam bean: cassava: wheat composite flour for sustainability in cake and chin-chin production. Annual report 2014 National Root Crops Research Institute, Umudike. pp. 219-221.

2. Kanika k (2010) Yam bean or singkamas production. Pinoyentre.

3. A report on American yam bean trial, (2015) at Igbariam sub-station, Anambra State Nigeria by udemezue, JC Unpublished work.

4. (2013) Partnership for yam bean. New Agriculturist.

5. Amadi CO, Egesi CN, Amajor E, Ironkwe AG (2014) Evaluation of newly introduced American yam bean and genotype in Nigeria. Annual report 2014 National Root Crops Research Institute, Umudike, pp. 65-66.

6. Karly H, Joachin H (1998) Promoting the conservation and use of underutilized and neglected crop. 2: 90-95.

\section{Your next submission with Juniper Publishers will reach you the below assets}

- Quality Editorial service

- Swift Peer Review

- Reprints availability

- E-prints Service

- Manuscript Podcast for convenient understanding

- Global attainment for your research

- Manuscript accessibility in different formats

( Pdf, E-pub, Full Text, Audio)

- Unceasing customer service

Track the below URL for one-step submission https://juniperpublishers.com/online-submission.php 